\title{
PEMODELAN DATA COVID-19 MENGGUNAKAN REGRESI POLINOMIAL LOKAL
}

\section{MODELING OF COVID-19 DATA USING LOCAL POLYNOMIAL REGRESSION}

\author{
Rory ${ }^{1}$, Rita Diana ${ }^{2}$ \\ 1, 2 Badan Pusat Statistik Provinsi Sumatera Barat \\ JL. Khatib Sulaiman No. 48, Padang, Sumatera Barat, Indonesia \\ E-mail: rory@bps.go.id
}

\begin{abstract}
ABSTRAK
Provinsi DKI Jakarta menempati urutan teratas total kasus terkonfirmasi Covid-19 di Indonesia. Tujuan penelitian ini adalah memodelkan data Covid-19 di DKI Jakarta tersebut menggunakan model regresi polinomial lokal dan melakukan prediksi untuk beberapa hari ke depan. Derajat polinomial lokal yang digunakan dibatasinya hanya untuk derajat polinomial 0 (lokal konstan), 1 (lokal linier), 2 (lokal kuadratik), dan 3 (lokal kubik). Jenis kernel yang digunakan adalah kernel Gaussian dan bandwidth optimum diperoleh dengan metode GCV. Bandwidh optimum untuk pemodelan regresi polinomial lokal derajat $0,1,2$, dan 3 masing-masing adalah 17,57, 22,18, 44,37 dan 48,26. Regresi polinomial lokal derajat 1 dianggap sebagai model regresi polinomial lokal terbaik karena memiliki nilai MSE paling kecil yaitu $2.446,99$. Selanjutnya regresi polinomial lokal terbaik digunakan untuk melakukan prediksi jumlah kasus baru positif harian Covid-19 di DKI Jakarta beberapa hari ke depan. Nilai MAPE hasil prediksi adalah 15,96 persen, dimana berdasarkan nilai tersebut regresi polinomial lokal derajat 1 sudah dapat dikatakan baik dalam melakukan prediksi.
\end{abstract}

Kata kunci: covid-19, polinomial lokal

\section{ABSTRACT}

DKI Jakarta Province ranks at the top of the total confirmed cases of Covid-19 in Indonesia. The purpose of this study is to model the Covid-19 data in DKI Jakarta using a local polynomial regression model and make predictions for the next few days. The degree of local polynomial used is limited to degrees of polynomials 0 (local constant), 1 (local linear), 2 (local quadratic), and 3 (local cubic). The type of kernel used is the Gaussian kernel and the optimum bandwidth is obtained by the GCV method. The optimum bandwidh for local polynomial regression modeling degrees 0, 1, 2, and 3 are 17.57, 22.18, 44.37 and 48.26, respectively. Local polynomial regression of degree 1 is considered the best local polynomial regression model because it has the smallest MSE value, namely 2,446.99. Furthermore, the best local polynomial regression is used to predict the number of new positive daily cases of Covid-19 in DKI Jakarta in the next few days. The predicted MAPE value is 15.96 percent, which is based on this value, the local polynomial regression degree 1 can be said to be good in making predictions.

Keywords: covid-19, polinomial lokal

\section{PENDAHULUAN}

Coronavirus Disease 2019 (Covid-19) adalah penyakit menular yang disebabkan oleh Severe Acute Respiratory Syndrome Coronavirus-2 (Sars-CoV-2). Sars-CoV-2 adalah keluarga virus jenis baru yang belum teridentifikasi sebelumnya pada manusia. Penularan virus sebagian besar melalui batuk, bersin atau interaksi manusia satu sama lain untuk beberapa waktu dalam jarak yang dekat. Tanda dan gejala umum terinfeksi Sars-CoV-2 antara lain gejala gangguan pernafasan akut seperti demam, batuk, dan sesak nafas. Pada kasus Covid-19 yang berat dapat menyebabkan pneunomia, sindrom pernafasan akut, gagal ginjal dan bahkan kematian (Kementerian Kesehatan RI, 2020). 
Penyebaran Covid-19 ini sangat cepat di berbagai negara di dunia termasuk juga di Indonesia. Hasil pemantauan dari Kementerian Kesehatan RI, hingga tanggal 20 Agustus 2020, total kasus terkonfirmasi Covid-19 di Indonsia adalah 147.211 kasus dengan 6.418 kematian (CFR 4,36\%). Provinsi DKI Jakarta menempati urutan teratas total kasus terkonfirmasi Covid-19 di Indonesia yaitu 31.610 kasus dengan 1.048 kematian (CFR 3,32\%).

Berbagai upaya telah dilakukan oleh pemerintah, khususnya pemerintah Provinsi DKI Jakarta sebagai ibukota negara, mulai dari mengeluarkan kebijakan menjaga jarak aman antar warga dalam bermasyarakat (social distancing measure) dan membatasi aktifitas keluar rumah dengan menutup sementara berbagai fasilitas umum, kegiatan pembelajaran di rumah ( home learning), bekerja dari rumah (work from home), bahkan peniadaan sementara kegiatan peribadatan dan keagamaan di rumah ibadah, termasuk juga kebijakan melakukan pemberlakuan pelaksanaan pembatasan sosial berskala besar dalam upaya memutus mata rantai penyebaran Covid-19. Namun hingga kini, penyebaran virus Covid-19 tetap saja tidak menunjukkan tanda-tanda penurunan.

Tujuan penelitian ini adalah memodelkan data Covid-19 menggunakan model regresi polinomial lokal. Penelitian sebelumnya mengenai pemodelan regresi polinomial lokal untuk data Covid-19 dapat dilihat dalam Gregori, dkk., 2020 dan Roux, Massonnaud, \& Crépey, 2020.

Model terbaik regresi polinomial dalam penelitian ini akan digunakan untuk memprediksi total kasus penyebaran Covid-19 beberapa hari ke depan. Penelitian ini diharapkan dapat memberikan informasi tambahan bagi Pemerintah Provinsi DKI Jakarta untuk bersiap menghadapi apa yang akan terjadi dalam waktu dekat dalam rangka penanganan Covid-19.

\section{METODE}

Data yang digunakan dalam penelitian ini adalah data jumlah kasus baru positif harian Covid19 di DKI Jakarta sejak tanggal 16 Maret 2020 sampai dengan 20 Agustus 2020 yang bersumber dari website Covid-19 Pemerintah Provinsi DKI Jakarta, 2020. Data tersebut akan dimodelkan menggunakan regresi polinomial lokal terbaik. Variabel yang akan dianalisis adalah jumlah kasus baru positif harian Covid-19 yaitu sebagai variabel dependen dan variabel waktu (hari) sebagai variabel independen. Data akan dibagi menjadi dua kelompok yaitu data in sample yang digunakan untuk membentuk model regresi polinomial lokal, dan data out sample yang digunakan untuk memvalidasi model.

Tinjauan mengenai estimasi regresi polinomial lokal dapat dilihat dalam Fan \& Gijbels (1996). Regresi polinomial lokal merupakan salah satu dari regresi nonparametrik. Dalam regresi nonparametrik, jika diberikan pasangan data $\left(x_{i}, y_{i}\right), i=1,2, \ldots, n$, maka hubungan $y$ dan $x$ dapat ditulis menjadi

$$
y_{i}=\mu\left(x_{i}\right)+\epsilon_{i},
$$

dimana $\mu(x)$ merupakan fungsi regresi dan $\epsilon$ adalah error random. Dalam regresi nonparametrik fungsi $\mu(x)$ diasumsikan tidak diketahui bentuknya dan tidak ada asumsi yang harus dipenuhi untuk fungsi tersebut. Fungsi $\mu\left(x_{i}\right)$ pada model (1) dapat diestimasi menggunakan estimator polinomial lokal. Estimator polinomial lokal mengadopsi dari perluasan deret Taylor di sekitar $x_{0}$. Perluasan deret Taylor untuk $x$ disekitaran $x_{0}$ dengan derajat polinomial lokal sama $p$ adalah

$$
\mu(x) \approx \sum_{j=0}^{p} \frac{m^{j}\left(x_{0}\right)}{k !}\left(x-x_{0}\right)^{j} \equiv \sum_{j=0}^{p} \beta_{j}\left(x-x_{0}\right)^{j} .
$$


Parameter $\beta_{j}$ bergantung pada titik $x_{0}$ yang disebut dengan titik lokal. Parameter tersebut dapat diestimasi menggunakan Weighted Least Square (WLS) dengan meminimumkan fungsi

$$
\min _{\beta_{j} \in \mathbb{R}} \sum_{i=1}^{n}\left\{y_{i}-\sum_{j=0}^{p} \beta_{j}\left(x_{i}-x_{0}\right)^{j}\right\}^{2} K_{h}\left(x_{i}-x_{0}\right) .
$$

$K_{h}()=.K(. / h) / h$ adalah fungsi kernel yang sifatnya bernilai riil, kontinu, terbatas dan simetris dengan $\int K(z) d z=1$, sedangkan $h$ merupakan bandwidth yang mengontrol ukuran persekitaran titik lokal $x_{0}$. Permasalahan WLS pada persamaan (2) dalam bentuk matriks dapat ditulis menjadi

$$
\min _{\beta}\left\{(\mathbf{y}-\mathbf{X} \boldsymbol{\beta})^{T} \mathbf{W}(\mathbf{y}-\mathbf{X} \boldsymbol{\beta})\right\}
$$

dimana $\boldsymbol{y}=\left(y_{1}, \ldots, y_{n}\right)^{T},=\left(\beta_{1}, \ldots, \beta_{p}\right)^{T}$,

$$
\mathbf{X}=\left(\begin{array}{cccc}
1 & \left(x_{1}-x_{0}\right) & \cdots & \left(x_{1}-x_{0}\right)^{p} \\
\vdots & \vdots & \ddots & \vdots \\
1 & \left(x_{n}-x_{0}\right) & \cdots & \left(x_{n}-x_{0}\right)^{p}
\end{array}\right)
$$

dan $\mathbf{W}=\operatorname{diag}\left\{K_{h}\left(x_{i}-x_{0}\right)\right\}$ yang berukuran $n \times n$. Hasil estimasi parameter $\boldsymbol{\beta}$ dengan WLS adalah

$$
\widehat{\boldsymbol{\beta}}=\left(\mathbf{X}^{T} \mathbf{W} \mathbf{X}\right)^{-1} \mathbf{X}^{T} \mathbf{W} \mathbf{y} .
$$

Ada beberapa komponen yang harus ditentukan untuk membuat regresi polinomial lokal, yaitu derajat polinomial, fungsi kernel dan bandwidth atau paramete penghalus. Pada penelitian ini, derajat polinomial yang digunakan adalah 0, 1, 2 dan 3. Regresi polinomial lokal derajat 0 disebut juga dengan estimator lokal konstan atau estimator Nadaraya-Watson, estimator polinomial lokal derajat 1 disebut dengan estimator lokal linier, sedangkan estimator polinomial lokal derajat 2 dan 3 disebut dengan estimator lokal kubik dan lokal kuadratik.

Fungsi kernel diberlakukan pada setiap titik pada data. Beberapa contoh fungsi kernel yang digunakan adalah Gaussian, Epanechnikov, Cosinus, Uniform, dan Triangle. Penelitian ini menggunakan fungsi kernel Gaussian digunakan karena fungsi ini dianggap lebih smooth dibandingkan fungsi kernel yang lain. Bentuk fungsi kernel gaussian adalah

$$
K(z)=\frac{1}{\sqrt{2 \pi}} \exp \left(-\frac{1}{2} z^{2}\right)
$$

Bandwidth atau parameter penghalus menentukan berapa banyak data yang digunakan untuk menyesuaikan setiap polinomial lokal. Bandwidth $h$ sangat menentukan kemulusan dari kurva regresi. Jika bandwidth diperkecil maka kurva regresi akan semakin kasar sehingga bias semakin kecil namun varian akan membesar, sebaliknya jika bandwidth diperbesar, maka varian akan mengecil, namun varian akan membesar. Oleh karena itu, diperlukan keseimbangan bias dan varian melalui pemilihan pemilihan bandwidth optimum yang menghasilkan mean squared error (MSE) terkecil. Salah satu metode untuk jumlah kasus baru positif harian Covid-19 di DKI Jakarta mendapatkan bandwidth optimum adalah metode GCV (Golub, Heath, \& Wahba, 1979),

$$
G C V(h)=\frac{1}{n} \sum_{i=1}^{n}\left(\frac{y_{i}-\hat{\mu}\left(x_{i} ; h\right)}{1-\operatorname{tr}(\mathbf{L}(h))}\right)^{2},
$$


dimana $\mathbf{L}(h)=\mathbf{X}\left(\mathbf{X}^{T} \mathbf{W}(h) \mathbf{X}\right)^{-1} \mathbf{X}^{T} \mathbf{W}(h)$. Nilai bandwidth minimum adalah nilai bandwidth pada saat nilai GCV berada pada nilai minimum.

\section{HASIL DAN PEMBAHASAN}

Grafik perkembangan jumlah kasus baru positif harian Covid-19 di DKI Jakarta mulai tanggal 16 Maret 2020 sampai dengan 20 Agustus 2020 terlihat pada Gambar 1. Pada grafik tersebut, jumlah kasus baru positif harian Covid-19 setiap harinya selalu naik turun, namun secara umum grafik tersebut cenderung naik. Kenaikan yang cukup signifikan terjadi mulai Juli 2020.

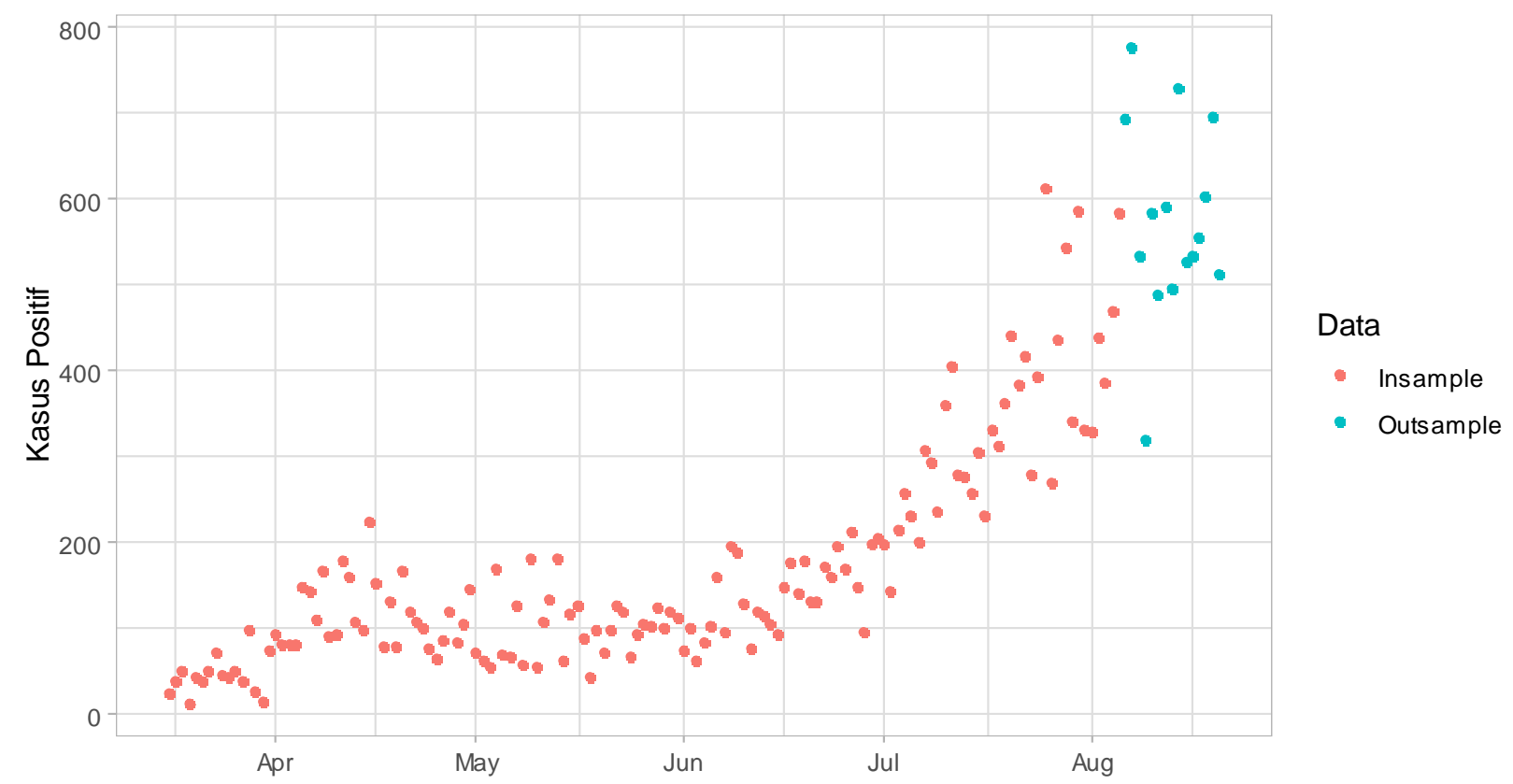

Gambar 1. Jumlah orang terkonfirmasi positif Covid-19 tanggal 16 Maret - 20Agustus 2020

Jumlah data yang di plot pada Gambar 1 adalah 158 data (158 hari) yang dibagi menjadi 2 yaitu data tanggal 16 Maret 2020 sampai dengan 5 Agustus 2020 (143 data) sebagai data in sample dan data data tanggal 6 Agustus 2020 sampai dengan 20 Agustus 2020 (15 data) sebagai data out sample. Data in sample digunakan untuk membentuk regresi polinomial lokal derajat 0, 1, 2 dan 3. Sedangkan data out sample digunakan untuk validasi model.

Langkah pertama yang dilakukan sebelum membentuk model regresi polinomial lokal adalah melakukan pemilihan bandwidth untuk setiap regresi polinomial lokal. Bandwidth yang dipilih adalah bandwidth optimal, dimana bandwidth optimal diperoleh ketika nilai bandwidth yang digunakan pada regresi polinomial lokal memiliki nilai GCV minimal. Nilai bandwidth dan GCV setiap regresi polinomial lokal derajat 0 sampai dengan 3 dapat dilihat pada Gambar 2. 


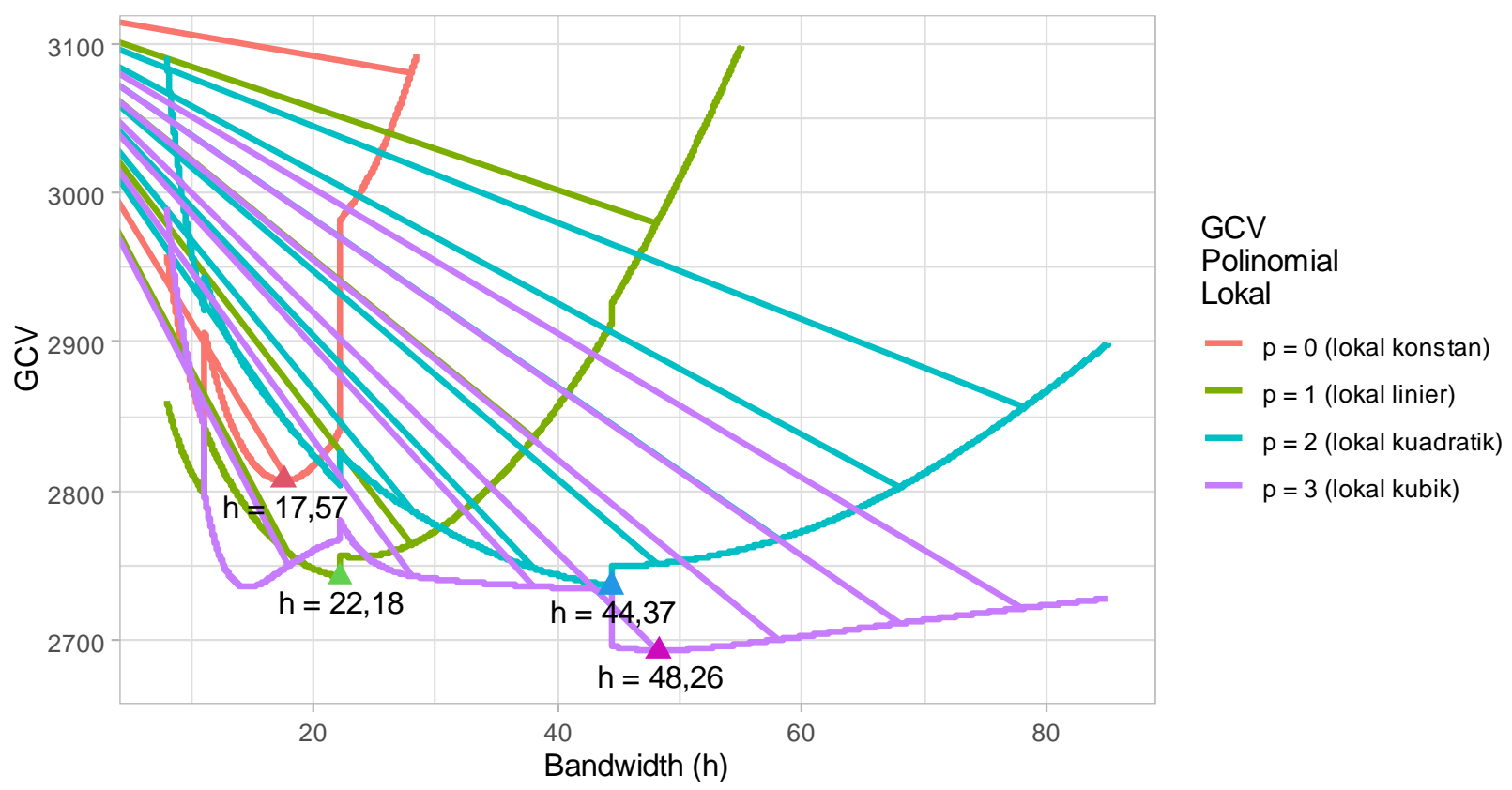

Gambar 2. Nilai bandwidth dan GCV Regresi Polinomial Lokal Derajat 0, 1, 2, dan 3

Tabel 1 menunjukkan bahwa, bandwidth optimum pada regresi polinomial lokal derajat 0 adalah 17,57 dengan GCV minimum 2.806,65, bandwidth optimum pada regresi polinomial lokal derajat 1 adalah 22,18 dengan GCV minimum 2.742,25, bandwidth optimum pada regresi polinomial lokal derajat 2 adalah 44,37 dengan GCV minimum 2.735,84, dan bandwidth optimum pada polinomial lokal derajat 3 adalah 48,26 dengan GCV minimum 2.692,64.

Tabel 1. Nilai GCV Minimum dan Bandwidth Optimum Regresi Polinomial Lokal

\begin{tabular}{ccccc}
\hline & \multicolumn{3}{c}{ Derajat Polinomial Lokal } \\
\cline { 2 - 5 } & $p=0$ & $p=1$ & $p=2$ & $p=3$ \\
\hline $\begin{array}{c}\text { GCV Minimum } \\
(\text { GCV.min })\end{array}$ & $2.806,65$ & $2.742,25$ & $2.735,84$ & $2.692,64$ \\
$\begin{array}{c}\text { Bandwidth Optimum } \\
(\text { h.opt })\end{array}$ & 17,57 & 22,18 & 44,37 & 48,26 \\
\hline
\end{tabular}

Masing-masing bandwidth optimum digunakan dalam pemodelan regresi polinomial lokal. Kurva regresi polinomial lokal derajat 0 sampai dengan 3 dapat dilihat pada Gambar 3. Keempat kurva regresi polinomial tersebut sangat mirip karena terlihat berhimpitan. Yang agak berbeda adalah pada regresi polinomial lokal derajat 0 dimana bagian ujung kurva berbeda dengan regresi polinomial lokal derajat yang lain. 


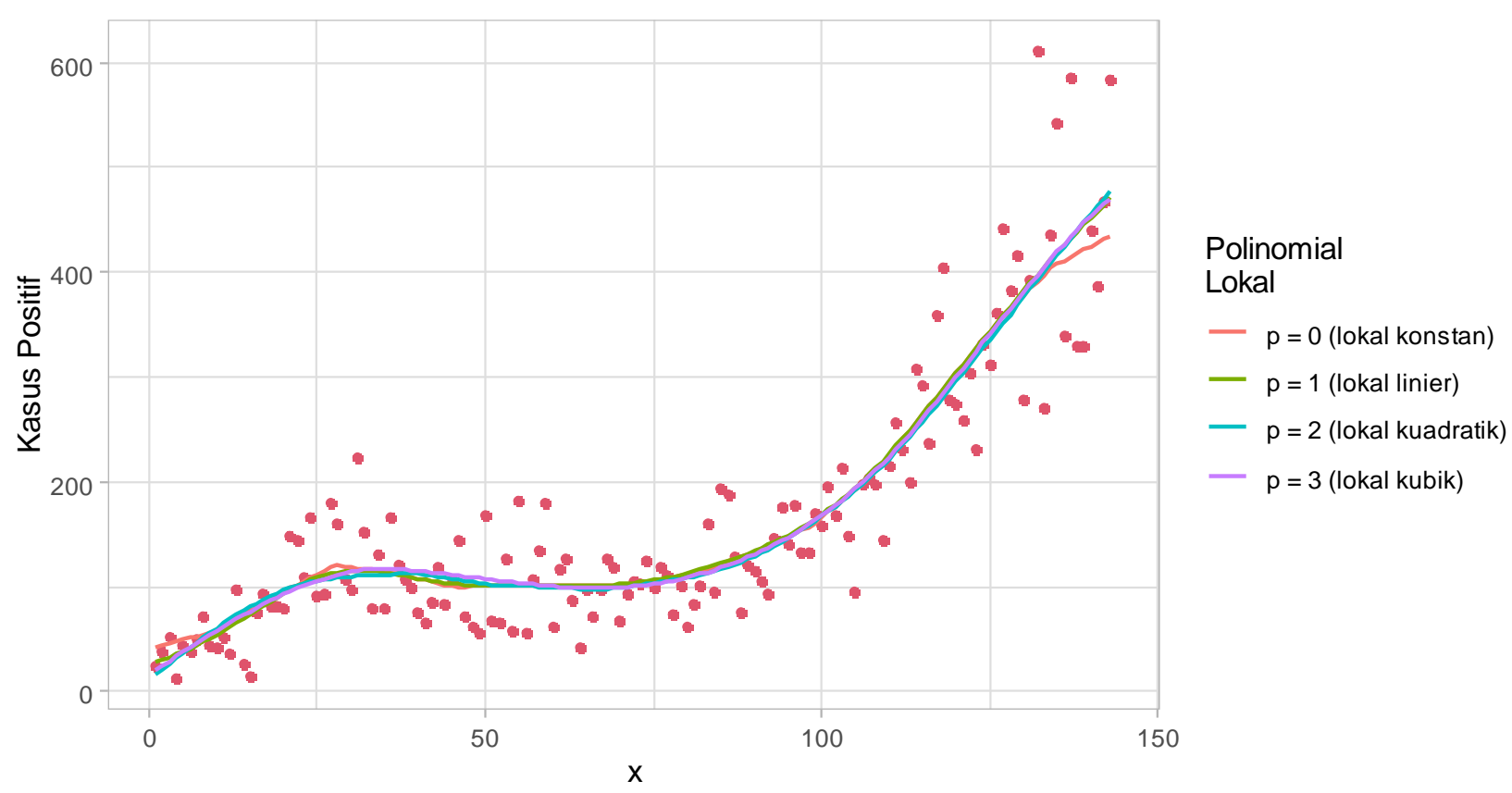

Gambar 3. Kurva Regresi Polinomial Lokal Derajat 0, 1, 2 dan 3

Evaluasi model menggunakan R2 dan MSE sebagaimana yang ditunjukkan oleh Tabel 2 bahwa R2 egresi polinomial Ikal derajat 0, 1, 2, dan 3 masing masing adalah 76,12, 83,58, 82,19 dan 82,93, sedangkan MSE 2.475,32; 2.446,99; 2.494,28; dan 2.479,69. Regresi polinomial lokal derajat 1 dianggap sebagai model terbaik karena memiliki nilai MSE terkecil.

Tabel 2. Nilai $R^{2}$ dan MSE Regresi Polinomial Lokal

\begin{tabular}{crrrr}
\hline & \multicolumn{4}{c}{ Derajat Polinomial Lokal } \\
\cline { 2 - 5 } & \multicolumn{1}{c}{$p=0$} & $p=1$ & $p=2$ & \multicolumn{1}{c}{$p=3$} \\
\hline$R^{2}$ & 76,12 & 83,58 & 82,19 & 82,93 \\
$M S E$ & $2.475,32$ & $2.446,99$ & $2.494,28$ & $2.479,69$ \\
\hline
\end{tabular}

Model regresi polinomial lokal derajat 1 ini selanjutnya digunakan untuk melakukan prediksi data out sample. Hasil prediksi dadri model regresi polinomial lokal derajat 1 dapat dilihat pada Gambar 4. Nilai MAPE hasil prediksi yang diperoleh adalah sebesar 15,96 persen. Berdasarkan kriteria interpretasi penilaian MAPE (Lewis, 1982), model regresi polinomial lokal derajat 1 tersebut sudah dapat dikatakan baik dalam melakukan prediksi. 


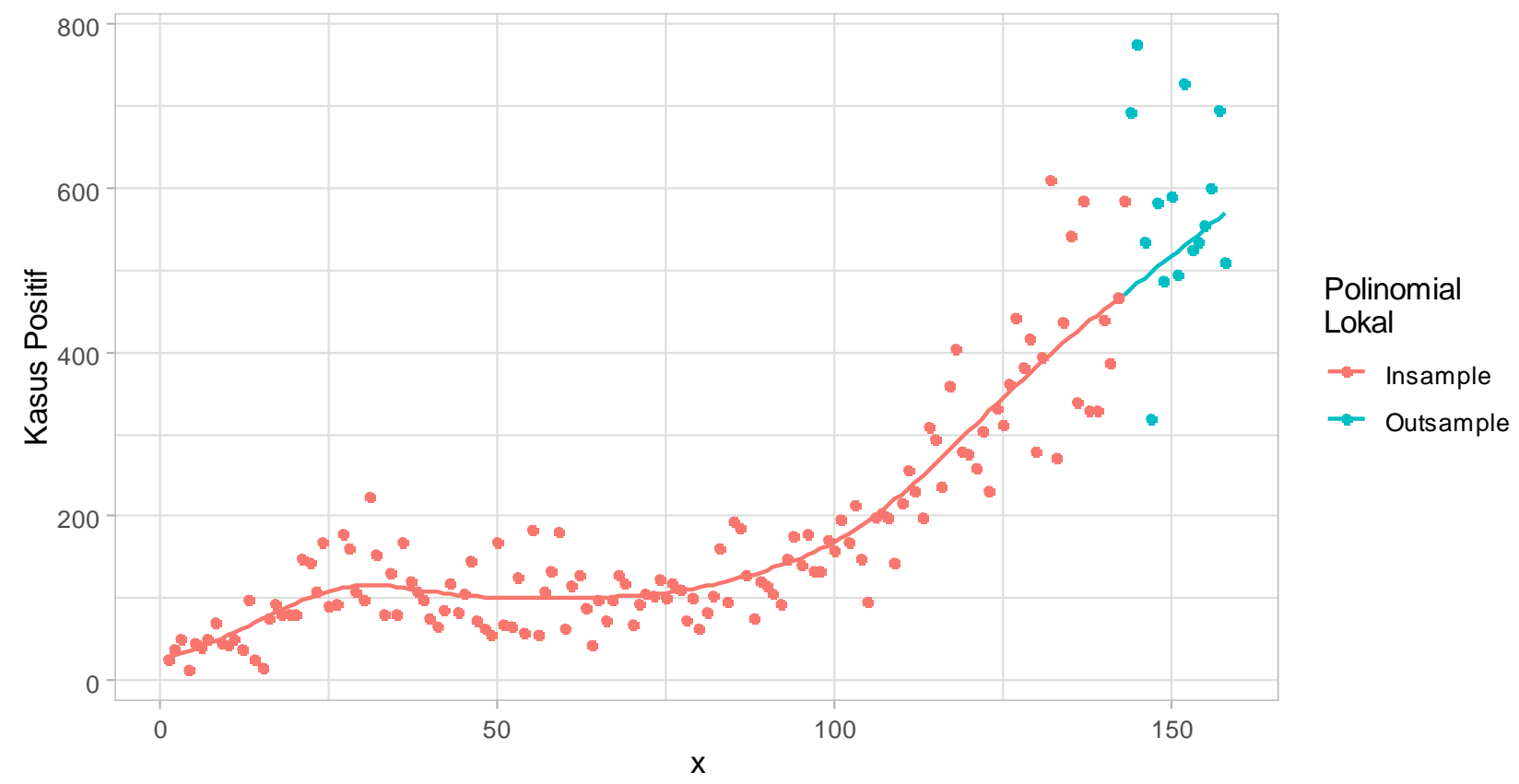

Gambar 4. Kurva Regresi Polinomial Lokal Derajat 1 dan Prediksi15 Hari

\section{KESIMPULAN}

Regresi polinomial lokal derajat 1 (lokal linier) adalah model terbaik dibandingkan dengan regresi polinomial lokal yang lain dalam memodelkan jumlah kasus baru positif harian Covid-19 di DKI Jakarta. Regresi polinomial lokal derajat 1 juga cukup baik dalam memprediksi jumlah kasus baru positif harian Covid-19 beberapa hari ke depan. Penelitian ini diharapkan Pemerintah Provinsi DKI Jakarta untuk bersiap menghadapi apa yang akan terjadi dalam waktu dekat dalam rangka penangan Covid-19.

\section{DAFTAR PUSTAKA}

Fan, J., \& Gijbels, I. (1996). Local Polynomial Modelling and Its Applications: Monographs on Statistics and Applied Probability 66 (Vol. 66). CRC Press.

Golub, G. H., Heath, M., \& Wahba, G. (1979). Generalized Cross-Validation as a Method for Choosing a Good Ridge Parameter. Technometrics, 21(2), 215-223.

Gregori, D., Azzolina, D., Lanera, C., Prosepe, I., Destro, N., Lorenzoni, G., \& Berchialla, P. (2020). A first estimation of the impact of public health actions against COVID-19 in Veneto (Italy). J Epidemiol Community Health.

Kementerian Kesehatan RI. (2020). Pedoman Pencegahan dan Pengendalian Coronavirus Disease (Covid-19). Jakarta: Kementerian Kesehatan RI, Direktorat Jenderal Pencegahan dan Pengendalian Penyakit (P2P).

Kementerian Kesehatan RI. (2020, August 21). Situasi Terkini Perkembangan Coronavirus Disease (COVID-19) 21 Agustus 2020. Retrieved Agustus 27, 2020, from Infeksi Emerging: https://covid19.kemkes.go.id/situasi-infeksi-emerging/info-corona-virus/situasi-terkiniperkembangan-coronavirus-disease-covid-19-21-agustus-2020/\#.X1ZSnXn7TIU 
Lewis, C. D. (1982). Industrial and Business Forecasting Methods. London: Butterworths.

Pemerintah Provinsi DKI Jakarta. (2020). Data Pemantauan Covid-19 DKI Jakarta. Retrieved August 27, 2020, from Jakarta Tanggap Covid-19: https://corona.jakarta.go.id/id/data-pemantauan

Roux, J., Massonnaud, C., \& Crépey, P. (2020). COVID-19: One-month impact of the French lockdown on the epidemic burden. medRxiv. 